Araştırma Makalesi - Research Article

\title{
İş Güvenliği Uzmanlarında İşe Bağlılığın ve İş Stresinin İSG Performansına Etkisi: Yapısal Eşitlik Modelleme Çalışması
}

\section{The Effect of Work Commitment and Work Stress on OHS Performance of Occupational Safety Specialists: Structural Equation Modelling Study}

\section{Zeynep Feride OLCAY* \\ (iD) 0000-0001-5720-7350}

\author{
Ahmet Ebrar SAKALLI** \\ (iD) 0000-0003-0445-0722 \\ Sertaç TEMUR ${ }^{* * *}$ \\ (iD) 0000-0003-4845-1452 \\ ÖZ
}

$\mathrm{Bu}$ çalışmanın amacı, iş sağlığı ve güvenliği (İSG) uygulamaları ile iş stresi ve işe bağlılık değişkenleri arasındaki ilişkileri incelemektir. Ölçüm tekniği olarak anket yöntemi kullanılmıştır. Ankete katılan 101 kişi İstanbul'da bulunan farklı sınıflarda iş güvenliği belgelerine sahip iş güvenliği uzmanları ve iş güvenliği teknikerlerinden oluşmaktadır. Araştırmada, sosyo-demografik bilgi formu, ISG Uygulamaları Performans Ölçeği, İş Stresi Ölçeği ve İşe Bağlılık Ölçeği kullanılmıştır. Yapılan analizler sonucunda iş stresi ile işe bağlılık arasında negatif bir ilişki bulunurken, işe bağlılık ile ISG Uygulamaları performansı arasında pozitif bir ilişki saptanmıştır. Bu çalışmanın sonunda, iş stresinin kurumlarda ortadan kaldırılması ya da en alt seviyeye indirilmesi, dolaylı olarak ISG performansını etkilediği ve bununla birlikte yönetimin katıldığı ve iletişimin yüksek olmasının İSG uygulamalarına olan bağlılığ 1 artırarak iş kazalarının gerçekleşmesine olumsuz; güvenlik kültürünün oluşturulmasına ise olumlu bir etki yarattığı sonucuna varılmıştır.

Anahtar Sözcükler: İş sağlığ1 ve güvenliği, iş stresi, işe bağlılık, politika, iş güvenliği uzmanı

\begin{abstract}
The aim of this study is to examine the relationships between occupational health and safety (OHS) practices, job stress and work commitment variables. Questionnaire method was used as the measurement technique. 101 people participating in the survey consist of occupational safety experts and occupational safety technicians with different classes of occupational safety certificates in Istanbul. Socio-demographic information form, OHS Practices Performance Scale, Job Stress Scale and Work Commitment Scale were used in the study. As a result of the analysis, a negative relationship is found between work stress and work commitment, while a positive relationship is found between work commitment and OHS practices performance.In conclusion, eliminating or minimizing work stress in institutions indirectly affects OHS performance and the involvement of the management and high communication with it increases the commitment to OHS practices and negatively to the occurrence of occupational accidents; It has been concluded that it has a positive effect on establishing a safety culture.
\end{abstract}

Keywords: Occupational health and safety, workrelated stress, work commitment, politics, occupational safety specialist

Önerilen atıf şekli: Olcay, Z. F., Sakallı, A. E. ve Temur, S. (2021). İş Güvenliği Uzmanlarında İşe Bağl1lığın ve İş Stresinin İSG Performansına Etkisi: Yapısal Eşitlik Modelleme Çalışması. Sosyal Güvenlik Dergisi (Journal of Social Security). 11(1). 141-156

• Geliş Tarihi/Received: 30/04/2021 • Güncelleme Tarihi/Revised: 26/05/2021 • Kabul Tarihi/Accepted: 14/06/2021

\footnotetext{
Dr. Öğr. Üyesi, İstanbul Aydın Üniversitesi, Anadolu BİL MYO, İş Sağlığı ve Güvenliği Programı, zeynepolcay@aydin.edu.tr

** Öğr. Gör., İstanbul Aydın Üniversitesi, Anadolu BİL MYO, İş Sağlı̆̆g ve Güvenliği Programı, ahmetsakalli@aydin.edu.tr

*** Arş. Gör., İstanbul Yeni Yüzyıl Üniversitesi, Sağlık Bilimleri Fakültesi, İş Sağlığı ve Güvenliği Bölümü, sertac.temur@yeniyuzyil.edu.tr
} 


\section{GíRIŞ}

İşletmelerde iş sağlığı ve güvenliği (İSG) konusunda çalışmalar yapılması, güvenlik kültürü kavramının tüm toplumlara benimsetilmesi, iş kazaları ve meslek hastalıklarını önlemesi özellikle son yıllarda tüm dünyada ve ülkemizde önem verilen bir konu ve sorun haline gelmiştir.

Ülkemizde de her yıl çok fazla sayılara ulaşan ölüm ve yaralanmalarla sonuçlanan iş kazalarının önüne geçebilmek adına 2012 yılında yürürlüğe girmiş olan 6331 Sayılı ISG Kanunu'yla birtakım yenilikler getirilmiştir. Bahsi geçen kanuna göre işverenin yükümlülüklerinden biri olan işyerinin tehlike sınıfı ve çalışan sayısına göre İSG hizmetlerini almaktır. Bu hizmeti alınması İSG profesyonelleri yani iş güvenliği uzmanı, işyeri hekimi ve diğer sağlık personeli görevlendirilmesini kastetmektedir. İşverenler bu hizmeti alırken İSG profesyonellerini kendi bünyesinde bulundurabileceği gibi Ortak Sağlık ve Güvenlik Birimi (OSGB) desteğiyle de karşılayabilmektedir (İSG Kanunu, 2012). İşverenin İSG hizmeti yükümlülüğünü yerine getirmek için görevlendirilen İSG profesyonellerinin en başta rehberlik etme görevi ile mevzuata göre işverenin diğer yükümlülüklerinin sağlanması konusundaki görev, sorumluluk ve yetkileri önemli bir yere sahiptir.

Çalışma ortamında İSG kuralları, İSG ile ilgili konuların bulunduğu ulusal ve uluslararası mevzuata göre uygulanmaktadır. Devletin bu konudaki yürütme ve uygulamalarının takibini yapmak üzere görevli olan ISG profesyonellerinin üzerine düşen sorumluluk çok büyük öneme sahiptir. Özellikle iş kazalarına neden olan teknik konuların takibinden sorumlu tutulan iş güvenliği uzmanları ve teknikerlerinin görevlerini yerine getirebilmeleri açısından işveren, yönetim ve çalışanların desteğine ihtiyaçları bulunmaktadır. Çalışma ortamındaki sağlık ve güvenlik şartlarının tam olarak sağlanamadığı durumlarda yaşanan iş kazaları ve meslek hastalıklarının önüne geçebilmek mümkün olmayacaktır. Bu bağlamda yönetim ve çalışanlar tarafından İSG'nin önemsenmediği durumlarda, İSG'nin sağlanamadığı çalışma alanları ve koşulları oluşacağından, özellikle teknik konularda destek veren İSG uzmanlarının gerek görev tanımları gerekse sorumlulukları yönünden stres altında bulunmaları kaçınılmaz olacaktır. Bu yaklaşımı destekleyen Michael ve diğerlerine göre (2005), örgütlerin İSG konularına önem vermeleri İSG ile ilgili yaşanan sıkıntıların azalmasının yanında örgütte çalışanların gerek davranışları gerekse tutumlarında da olumlu bir gelişme sağlamaktadır. İşyerinde strese neden olabilecek farklı kaynakların var olmasıyla beraber, iş güvenliği uzmanları ve teknikerleri için en etkili faktörün İSG uygulamalarına yeteri kadar önem verilmemesi olduğuna inanılmaktadır. İş güvenliği uzmanları ve teknikerlerinin iş stresi düzeylerinin doğrudan ya da dolaylı olarak işe bağlılıklarını etkilediği düşünülmektedir.

Literatürde, özellikle son yıllarda işe bağl1lık, iş stresi ve İSG performansı konusunda yapılan çok fazla sayıda ulusal ve uluslararası çalışmalar bulunmaktadır. Çınar ve Gündoğdu (2019) çimento ve tekstil sektöründe İSG uygulamaları ile iş tatmini ve işe bağlılık arasındaki ilişkiyi analiz etmişlerdir. Efeoğlu ve Özgen'in (2007) ilaç sektöründe çalışanlar üzerinde yapmış oldukları çalışmada iş -aile-yaşam çatışmasının iş stresi ve işe bağlılığa etkisi incelenmiştir. Uzun ve Yiğit (2011) otel işletmeleri, Şahin (2014) seyahat acentaları çalışanlarında, Alipour vd. (2015) hemşireler üzerinde, Bilgili ve Tekin (2019) ise kamu üniversitelerinde çalışan öğretim elemanlarının iş stresi ve işe bağlılıkları arasındaki ilişkiyi araştırmışlardır. Leung vd. (2015) inşaat sektöründe stres ve işe bağlılığın performansa olan etkileri üzerinde çalışma yapmıştır. İş kazalarının önlenmesinde önemli görev, yetki ve sorumlulukları bulunan, çok fazla stres faktörüne maruz kalan, İSG performansı algıları ve işe bağlılıklarının büyük önem arz ettiği düşünülen İSG profesyonellerinden iş güvenliği uzmanları için literatürde benzer çalışmalara rastlanmamıştır. $\mathrm{Bu}$ sebepten iş güvenliği uzmanları ve iş güvenliği 
teknikerlerinin iş stresinin, işe bağlılıkları üzerindeki etkisi ile iş stresi ve işe bağlılığın İSG Uygulamalarının performansı üzerindeki etkisi incelenmiştir.

\section{I- KAVRAMSAL ÇERÇEVE}

\section{A- İs Sağlığı ve Güvenliği}

Dünya Sağlık Örgütü (WHO) ve Uluslararası Çalışma Örgütü (ILO) tarafından onaylanan ortak "iş sağlığı kavramı tüm sektörlerde çalışan kişilerin fiziki, ruhi ve sosyal yönden tam iyilik hallerinin en üst seviyede bulundurulması, devamlılığının sağlanması ve geliştirilmesi; çalışanların sağlık açısından olumsuz faktörlerden kaynaklanan risklerden korunması; işçilerin fizyolojik ve psikolojik yeteneklerine uygun işlere yerleştirilmesi; özet olarak, işin insana ve insanın işe uyarlanması" şeklinde ifade edilmiştir (WHO, 1995).

Temel amacı işle ilgili yaralanmaları, hastalıkları ve ölümleri önleyerek işyeri güvenliğini ve sağlı̆̆ını güçlendirmeyi amaçlayan standartlar önererek, herhangi bir sektördeki çalışanını görev başında iken zarardan korumayı ilke edinen kavram olarak tanımlanan İSG (Bhagawati, 2015: 93), tıp, hukuk, teknoloji, ekonomi ve psikoloji gibi disiplinlerle ilgili konulara değinen multidisipliner bir kavramdır (Leka, 2003).

İSG Uygulamalarıyla, çalışanlar için uygun çalışma şartları sağlanarak işyerinin olumsuz etkilerinden çalışanları korumayı, sağlık koşullarını en üst seviyeye çıkararak, çalışanlar ile iş arasında bir uyum sağlanması amaçlanmaktadır. Aynı zamanda temel hedefi olan iş kazası ve meslek hastalıklarının önlenebilmesi için İSG Uygulamaları büyük bir önem taşımaktadır.

\section{B- İș Stresi}

Stres kavramı Latince "estrica", eski Fransızca "estrece" sözcüklerinden gelmektedir. Kavram 17. yüzyılda felaket, bela, dert, elem anlamlarında kullanılırken, 18. ve 19. yy'de kavram güç, zorluk, baskı gibi anlamlarda kullanılmaya başlanmıştır (Akgemci, 2001: 302).

Modern toplumlarda bir hastalık olarak ifade edilen stres kavramı için (Güçlü, 2001: 92), literatürde birbirinden farklı çok fazla tanım bulunmaktadır. Stresi, "kendisine yapılan herhangi bir isteğe karşı insan vücudunun özel olmayan tepkisi olarak tanımlayan Selye (1976), tüm canlı varlıkların devamlı stres altında olduklarını ve stresin vücudun yıpranmasına neden olan hoş ya da hoş olmayan her şey olarak açıklamıştır. Yapılan çalışmalar iş stresinin, çalışanların psikolojik ve fiziksel refahı üzerindeki olumsuz etkileriyle geniş bir şekilde ilişkilendirilmiştir (Kinman ve Jones, 2003: 33). Newbury-Birch ve Kamali (2001: 110) stresin yaşam kalitesini olumsuz etkilediği gibi insanların hem fiziksel hem de psikolojik iyilik hali için de bir tehdit olduğunu ifade etmiştir.

Stres, bir bireyin çalışma hayatının kaçınılmaz bir parçası olmakla beraber (Cooper, 1996), çalışanlar ve çalışma ortamında bir uyumun olmadığı sürece, iş hayatında çalışanların iş stresi yaşamaması gibi bir durumun söz konusu olamayacağı belirtilmektedir (Schuler, 1980: 189). Yani günlük yaşantımızdaki stres faktörlerinin yanında, yaşantımızın büyük bir bölümünü oluşturan çalışma ortamımızda da bir strese neden olabilecek farklı etmenlerle karşılaşabilmekteyiz.

İş stresi, iş ortamında çalışanların kapasiteleriyle çalışanlar üzerinde baskı yaratacak etkenlerin birbiriyle uyum içinde olmaması durumudur (Efeoğlu, 2006: 244). İş stresi ve depresyon arasında bir ilişki olduğu (Cho vd., 2008: 48), işyerinde yaşanan stresin boyutunun büyümesiyle beraber ilerleyen süreçte çalışanlarda, özellikle psikolojik olarak önemli sorunlar ortaya çıkabileceği bilinmektedir. Amerika Stres Kurumunun iş stresiyle ilgili değerlendirmesine göre, artan iş stresi seviyesinin çalışanlarda hipertansiyon, kalp krizi ve diğer bozukluklarla ilişkili olduğunu göstermektedir (Amerika Stres Kurumu, 2021). 


\section{C- İşe Bağlılık}

Lodahl ve Kejner (1965) tarafından yapılan işe bağllık kavramıyla ilgili çalışmalardan sonra işe bağlılık konusunda, çok fazla sayıda bilimsel araştırma yapılmıştır. Konunun önem kazanmasıyla beraber literatürde işe bağllıkla ilgili benzer tanımlar yer aldığ gibi, farklı ölçekler ve tanımların da çoğalmasıyla görüşlerde de farklılıklar ortaya çıkmıştır (Elloy vd., 1995). Kanungo'ya göre işe bağlllık kavramı, bilişsel seviyede işiyle özdeşleşmesidir (Sevim, 2011).

Çalışanların işlerine adanmışlık derecesi olarak ifade edilen işe bağllık, kişilerin işlerini yaşamlarının merkezinde bulundurmaları ve işlerini hayatlarının çok önemli bir parçası haline getirmeleridir. Kişilerin talep ve ihtiyaçlarına cevap verildiği taktirde işe bağlılık durumu oluşmaktadır (Dubinsky ve Hartley, 1986: 39; Rotenberry ve Moberg, 2007: 56). Bass (1965) işe bağllı̆ğı, çalışanların işyerinde karar verme yetkisi ve kişinin şirket başarısına önemli bir katkı sağladığı hissi olarak ifade etmiş̧tir.

İşe bağl1lık kavramı birden çok alt boyutta değerlendirilmektedir. Bu bağlamda işe bağl1lı̆̆1 oluşturan alt faktörler, işe karşı istekli olma, işe adanma ve işe yoğunlaşma olarak belirtilmektedir (Schaufeli vd., 2002: 75).

İşe bağllık farklı iki açıdan değerlendirilebilir. İlki kurum yani örgüt anlamında işe bağllıkken, diğeri bireysel anlamda işe bağllıktır. Örgüt tarafindan bakıldığında Lawler'a (1992) göre işe bağlılık, çalışanın motivasyonunu sağlayan bir kavramdır. Bireysel açıdan ise işe bağllık, kişisel gelişim, iş tatmini, motivasyon için kilit durumundadır. Brown'a (1996) göre eğer çalışanların işe bağlılıkları artarsa işleri daha da anlamlaşır, çalışanlar işlerine daha fazla yoğunlaşır ve dolayısıyla verimlilik ve performans da yükselir.

\section{GEREÇ VE YÖNTEM}

\section{A- Araştırmanın Örneklemi}

Örneklem seçiminde kullanılan araçlardan birisi mutlak örneklem büyüklüğüdür (Doğan, Soysal ve Karaman, 2017). Buna göre, Gorsuch (1983) ve Kline (1979) en az 100 örneklem olması gerektiğini belirtmişken, buna karşın Comrey ve Lee (2013) ise örneklem büyüklüğünü seçerken $100=$ zaylf, $200=$ orta, $300=$ iyi, $500=$ çok iyi ve $1000=$ mükemmel olarak ifade etmiştir.

$\mathrm{Bu}$ bilgiler doğrultusunda ve pandemi koşullarının etkisiyle birlikte alt sınır örneklem sayısı baz alınarak, araştırmanın örneklemi İstanbul ilinde çalışan rastgele seçilen 101 iş güvenliği uzmanı ve teknikerlerinden oluşturulmuştur. Anketler internet ortamında oluşturularak hedef kitle tarafından doldurulmuştur.

\section{B- Veri Toplama Araçları ve Ölçekler}

Çalışmada veriler, literatür taraması yapıldıktan sonra iş güvenliği uzmanları ve teknikerlerine uygulanmak üzere, sosyodemografik bilgilerin elde edilmesine yönelik bilgi formu, İSG Uygulamalarının performans değerlendirilmesi amacıyla Üngüren tarafından geliştirilmiş olan İSG Uygulamaları Performans Ölçeği, iş stresinin değerlendirilmesi için genel İş Stresi Ölçeği ve işe bağlllığın ölçülmesi için Uthrect işe bağllık ölçeği kullanılarak online anket uygulanarak toplanmıştır.

i) İs Sağlığı ve Güvenliği Uygulamaları Performans Ölçeği: İSG Uygulamalarının etkinliğinin performanslarını değerlendirmek adına Üngüren (2015) tarafından geliştirilmiş ölçeğin geçerli ve güvenilir bir yapıya sahip olduğu ve 5 faktörden oluştuğu belirlenmiştir. $\mathrm{Bu}$ alt boyutlar; iş sağlığı ve güvenliği konusunda yönetsel önlem ve tedbirler, çalışanların iş 
sağlığı ve güvenliği kriterlerine göre çalışması, çalışanların iş sağlığı ve güvenliği konusunda farkındalık ve bilinç düzeyleri, iş sağlığı ve güvenliği eğitim uygulamaları ve iş sağlığ 1 ve güvenliği konusunda yönetim ve çalışanlar arasında iş birliği ve iletişim'dir. İSG Uygulamaları performans ölçeği, 30 maddeden oluşan beşli Likert tipi bir araçtır.

ii) Genel İş Stresi Ölçeği: Teleş (2020) tarafından Türkçeye uyarlanan Genel İş Stresi Ölçeği (General Work Stress Scale) 5’li likert derecelendirme ölçeği ve 9 önermeden oluşmaktadır. $\mathrm{Bu}$ ölçek, çalışanın işyerinde yaşadığı stresle ilişkili olan psikolojik ve psikosomatik semptomlarını ölçmektedir. Genel iş stresi için Cronbach Alfa güvenilirlik katsayısı 0,91 olarak elde edilmiştir

iii) İşe Bağlılık Ölçeği: Utrecht Work Engagement Scale (UWES) ölçeği, Schaufeli ve ark. (2002) tarafından çalışanların işe bağlılıklarını ölçmek için geliştirilmiştir. UWES'in Türkçeye uyarlanması ile geçerlik ve güvenilirlik çalışmaları Eryılmaz ve Doğa (2012) tarafından yapılmıştır. İşe istek duyma (vigor), işe adanma(dedication) ve işe yoğunlaşma (absorption) olmak üzere ölçek 3 boyuttan oluşmaktadır. Ölçek geliştirme çalışmasında 24 önerme maddesi 17 maddeye düşürülmüştür ve 5'li likerte göre derecelendirilmiştir. Ölçekten alınan yüksek puanlar işe bağlılığın yüksek olduğunu göstermektedir.

İşe istek duyma alt boyutu, çalışanların iş görme edinimi sırasında yüksek enerjili, işe karşı hevesli ve ruhsal olarak dayanıklı olmalarını tanımlar, işe adanma alt boyutu çalışanların işlerini yaparken coşku, ilham, gurur ile yapmalarını ifade ederken işe yoğunlaşma alt boyutu ise çalışanın işine tamamen yoğunlaşması ve mutlu bir şekilde meşgul olmasıyla karakterize edilen, zamanın hızla geçtiği ve bireyin kendini işten ayırmakta zorluk yaşadığını ifade etmektedir (Hakanen, Bakker ve Schaufeli, 2006: 501).

Tablo 1'de araştırmada kullanılan anketlerin güvenirlik analiz sonuçları verilmiştir. Sonuçlara bakıldığında .94 ile en yüksek $\alpha$ değerine sahip ölçek Genel İş Stresi Ölçeği ve işe adanma alt boyutu olarak görülmektedir.

Tablo 1. Çalışmada Kullanılan Ölçeklerin Güvenirlik Analizi

\begin{tabular}{|c|c|c|}
\hline Ölçek Boyutları & $\begin{array}{c}\text { Madde } \\
\text { Sayısı }\end{array}$ & $\begin{array}{c}\text { Cronbach Alfa } \\
\text { Katsayisı }(\alpha)\end{array}$ \\
\hline İş Sağlığı ve Güvenliği Konusunda Yönetsel Önlem ve Tedbirler* & 348 & 80,4 \\
\hline Çalışanların İş Sağlığg ve Güvenliği Kriterlerine Göre Çalışması* & 85 & 18,7 \\
\hline $\begin{array}{l}\text { Çalışanların İş Sağlığı ve Güvenliği Konusunda Farkındalık ve Bilinç } \\
\text { Düzeyleri* }\end{array}$ & 22 & 4,8 \\
\hline \multicolumn{3}{|l|}{ İş Sağlığı ve Güvenliği Eğitim Uygulamaları* } \\
\hline \multicolumn{3}{|l|}{$\begin{array}{l}\text { İş Sağlığı ve Güvenliği Konusunda Yönetim ve Çalışanlar Arasında İş } \\
\text { Birliği ve İletişim* }\end{array}$} \\
\hline \multicolumn{3}{|l|}{ İşe İstek Duyma** } \\
\hline \multicolumn{3}{|l|}{ İşe Adanma** } \\
\hline \multicolumn{3}{|l|}{ İşe Yoğunlaşma** } \\
\hline \multicolumn{3}{|l|}{ Genel İş Stresi Ölçeği } \\
\hline $\begin{array}{l}\text { * İş sağlığı ve güvenliği uygulamaları performans değerlendirme ölçeğ } \\
\text { ** Utrecht işe bağlılık ölçeğinin alt boyutları }\end{array}$ & oyutları & \\
\hline
\end{tabular}




\section{C- Çalışmada Kullanılan Uyum İndeksleri}

Ki-kare (CMIN) analizi, uygulanan modelin uyumunu analiz eden en temel ve en çok kullanılan ölçüm yöntemlerinden birisidir. Bir başka uyum indeksi ki-kare serbestlik derecesi oranı $\mathrm{X}^{2 / s d}(\mathrm{CMIN} / \mathrm{DF})$ modelin uyumu açısından bir değerlendirme sağladığı ifade edilmektedir (Bayram, 2010: 88). Ki-kare serbestlik derecesi oran $0<\chi^{2 / s d} \leq 3$ ise modelin uyumundan söz edebiliriz (Mokarami vd., 2019).

Karşılaştırmalı uyum indeksi (CFI) bağımsız modele dayanan uyum indeksleri içinde CFI en fazla kullanılan indeks değeridir (Bayram, 2010: 87). 0,90 veya daha üstü CFI değeri kabul edilir uyumu gösterir. (Bryne, 2001; Aytaç ve Öngen, 2012: 17; Danish, Ramzan ve Ahmad, 2013: 315). Küçük örneklem için uygundur (Hsu vd., 2012: 4).

CFI denklemi (1);

$$
C F I=1-\frac{X_{m}^{2}-s d_{m}}{X_{b}^{2}-s d_{b}}
$$

$\mathrm{m}$; test edilen modeli, b; bağımsız modeli, sd; serbestlik derecesini göstermek üzere GFI uyum indeksi yukarıdaki gibi hesaplanır.

Standardize edilmiş kalıntıların ortalama kare kökü (SRMR), korelasyon ölçümündeki kalıntıların karelerinin toplamının kare köküdür (Bayram, 2010: 87). Yapısal eşitlik modellerinin uyumunu açıklarken bildirilen yaygın olarak kullanılan uyum indekslerinden biridir (Kline, 2010). 0.05'in altındaki değerler iyi bir uyumu gösterirken $0.05 \leq$ SRMR $\leq$ 0.10 kabul edilebilir uyum olduğunu göstermektedir (Bayram, 2010: 87).

SRMR denklemi (2);

$$
S R M R=\sqrt{\frac{2}{p(p+1)} \sum_{i \leq j}\left\{\left(s_{i j}-\sigma_{i j}(\theta)\right)\right\}^{2} / s_{i i} S_{j j}}
$$

Yukarıdaki formülde, $\sigma_{i j}(\theta) ; \sum \theta \operatorname{nin}(\mathrm{i}, \mathrm{j})$ ninci elemanıdır.

Bayesci bilgi kriteri (BIC), model uyumu için yaygın olarak kullanılan uyum indekslerinden biridir (Lin, Huang ve Weng, 2017: 861). Hipotez edilen modelin BIC değeri, doymuş modelden ve bağımsız modelden daha küçük olmalıdır (Bayram, 2010: 90).

Uyum indeksleri içerisinde en çok kullanılan indekslerden biri olan uyum iyiliği indeksi (GFI), model tarafından açıklanan varyans ve kovaryansın miktarının indeksidir. GFI değeri örneklem sayısı ile ilişkilidir. Örneklem sayısı arttıkça GFI değeri de artar. Bu durum doğru sonuç almayı engelleyebilir. GFI değeri 0 ile 1 arasında değişmektedir. GFI'ın $0,90 \leq$ GFI olması durumunda modelin uyum içerisinde olduğu kabul edilmektedir (MacCallum ve Hong, 1997: 203; Bayram, 2010: 89).

GFI denklemi (3);

$$
G F I=1-\left(\frac{X_{m}^{2}}{X_{b}^{2}}\right)
$$

$m$; test edilen modeli; $b$; bağımsız modeli göstermek üzere GFI uyum indeksi yukarıdaki gibi hesaplanır.

Araştırmanın amacı doğrultusunda ortalama, standart sapma, demografik bilgiler için SPSS 25.0, yapısal eşitlik ve yol analizi için AMOS 21.0 kullanılmıştır. 


\section{III- Bulgular}

\section{A- Demografik ve Tanımlayıcı Bilgiler}

Tablo 2'de araştırmanın demografik tablosu verilmiştir. Buna göre araştırmaya katılanların 40’1 $(\% 39,6)$ kadın, 61'i $(\% 60,4)$ erkek katılımcıdan oluşmaktadır. Ayrıca araştırmaya katılan iş güvenliği uzmanlarının sınıf düzeyine bakacak olursak A sınıfı $7(\% 6,9)$ kişi, B sınıfı $29(\% 28,7)$ kişi, C sınıfı $44(\% 43,6)$ kişi ve tekniker olarak $21(\% 20,8)$ kişiden oluşmaktadır.

Tablo 2. Demografik Bilgiler Tablosu

\begin{tabular}{|c|c|c|c|}
\hline & Değişken & Frekans $(\mathrm{N}=101)$ & $\%$ \\
\hline \multirow[t]{2}{*}{ Cinsiyet } & Erkek & 61 & 60,4 \\
\hline & Kadın & 40 & 39,6 \\
\hline \multirow{4}{*}{ Yaş } & $18-25$ & 39 & 38,6 \\
\hline & $26-33$ & 43 & 42,6 \\
\hline & $34-41$ & 7 & 6,9 \\
\hline & 42 ve üzeri & 12 & 11,9 \\
\hline \multirow{5}{*}{ Aylık gelir } & 3000£ Alt1 & 11 & 10,9 \\
\hline & 3001€-4000€ & 47 & 46,5 \\
\hline & 4001£-5000€ & 20 & 19,8 \\
\hline & 5001€-6000€ & 10 & 9,9 \\
\hline & 6000£ Üzeri & 13 & 12,9 \\
\hline \multirow{3}{*}{ Lisans eğitiminiz nedir? } & İSG Ön Lisans & 70 & 69,3 \\
\hline & İSG Lisans & 9 & 8,9 \\
\hline & Diğer Fakülte Mezunu & 22 & 21,8 \\
\hline \multirow[t]{2}{*}{ Medeni durum } & Evli & 28 & 27,7 \\
\hline & Bekar & 73 & 72,3 \\
\hline \multirow[t]{2}{*}{ Çocuk sahibi olma } & Evet & 83 & 82,2 \\
\hline & Hayır & 18 & 17,8 \\
\hline \multirow{5}{*}{$\begin{array}{l}\text { Çalıştığınız firmada kaç yıldır } \\
\text { çalışıyorsunuz? }\end{array}$} & 1 Yıldan Az & 50 & 49,5 \\
\hline & 1-3 Y1l Arası & 27 & 26,7 \\
\hline & 3-5Y1l Aras1 & 10 & 9,9 \\
\hline & 5-8 Y1l Aras1 & 11 & 10,9 \\
\hline & 8 Y1l ve Üzeri & 3 & 3,0 \\
\hline \multirow{5}{*}{$\begin{array}{l}\text { Kaç yıldır bu mesleği } \\
\text { yapıyorsunuz? }\end{array}$} & 1 Yildan Az & 20 & 19,8 \\
\hline & 1-3 Y1l Aras1 & 27 & 26,7 \\
\hline & 3-5Y1l Aras1 & 17 & 16,8 \\
\hline & 5-8 Y1l Aras1 & 27 & 26,7 \\
\hline & 8 Yil ve Üzeri & 10 & 9,9 \\
\hline \multirow[b]{2}{*}{ Çalışma türünüz? } & OSGB' ye bağlı olarak çalışıyorum. & 53 & 52,5 \\
\hline & $\begin{array}{l}\text { Firmanin kendi bünyesinde görev } \\
\text { yapıyorum. }\end{array}$ & 48 & 47,5 \\
\hline \multirow[t]{4}{*}{ İş güvenliği uzmanlık sınıfınız? } & A Sinıfi & 7 & 6,9 \\
\hline & B Sinıfi & 29 & 28,7 \\
\hline & C Sinıfi & 44 & 43,6 \\
\hline & Tekniker & 21 & 20,8 \\
\hline \multirow{2}{*}{$\begin{array}{l}\text { Şu an çalıştığınız işyerinde ölümlü } \\
\text { ya da ciddi yaralanmalı kaza oldu } \\
\text { mu? }\end{array}$} & Hayır & 78 & 77,2 \\
\hline & Evet & 23 & 22,8 \\
\hline
\end{tabular}


Tablo 3'te en yüksek ortalamaya sahip ölçek boyutu 3.99 ile iş sağlığı ve güvenliği eğitim uygulamaları, en düşük ortalamaya sahip ölçek boyutu ise 2.45 ile genel iş stresi olduğu saptanmıştır.

Standart sapma değerlerinde eğer standart sapma değeri küçük olduğu takdirde veriler ortalamaya yakın; standart sapma büyük ise, veriler ortalamadan uzak yerlerde dağıldığını göstermektedir (Atilla, 2017). Tablo 3'te bulunan SS değerlerine bakıldığında ortalamaya en yakın ölçeğin 68 standart sapma değeri ile "Çalışanların İş Sağlığı ve Güvenliği Kriterlerine Göre Çalışması” olduğu görülmektedir. En uzak ölçeğin ise 1.04 standart sapma değeri ile "İşe Adanma" alt boyutu olduğu görülmektedir.

Tablo 3. Ölçeklerin Ortalaması ve Standart Sapması

\begin{tabular}{|c|c|c|}
\hline Ölçek Boyutları & Ortalama $(\overline{\mathbf{x}})$ & Standart Sapma (SS) \\
\hline Genel İş Stresi Ölçeği & 2.45 & 1.02 \\
\hline $\begin{array}{l}\text { İş Sağlığı ve Güvenliği Uygulamaları Performans } \\
\text { Değerlendirme Ölçeği }\end{array}$ & 3.73 & .75 \\
\hline Utrecht İşe Bağlılık Genel & 3.64 & .89 \\
\hline $\begin{array}{l}\text { Çalışanların İş Sağlığı ve Güvenliği Kriterlerine Göre } \\
\text { Çalışması* }\end{array}$ & 3.54 & .68 \\
\hline $\begin{array}{l}\text { Çalışanların İş Sağlığı ve Güvenliği Konusunda } \\
\text { Farkındalık ve Bilinç Düzeyleri* }\end{array}$ & 3.51 & .86 \\
\hline İş Sağlığı ve Güvenliği Eğitim Uygulamaları* & 3.99 & .88 \\
\hline
\end{tabular}

\section{B- Yapısal Eşitlik Modeli (YEM)}

Tablo 4. Uygulanan Modelin Uyum Kriterleri

\begin{tabular}{lcccccc}
\hline Model & P & CMIN/DF & SRMR & GFI & BIC & CFI \\
\hline Default model & $*$ & 2,35 & .08 & .78 & 447.93 & .91 \\
\hline Saturated model & & & & & 706.11 \\
\hline Independence model & & & 1865.79 \\
\hline$* *$ p değerinin 0.01' den küçük olduğunu ifade eder, CMIN=Ki-kareyi ifade eder. & & \\
\hline \hline
\end{tabular}

Tablo 4'te görüldüğü gibi uygulanan modelin uyum indekslerinden GFI dışındaki bütün uyum indeksleri modelin iyi uyum içerisinde olduğunu göstermektedir. Ancak GFI indeksinin örneklem sayısı ile ilişkisi olduğunu dile getirmiştik. Örnek sayısına baktığımızda bununla ilişkili olduğu örneklem sayısı arttıkça GFI değeri de artar (MacCallum ve Hong, 1997: 201). Bu durumu göz önüne almak gerekir. YEM'de birden fazla uyum kriterine bakıldığı için uyum kriterlerinin çoğu uyum gösterdiği sürece model kabul edilmektedir (Bayram, 2010: 104). Bu nedenle modelimiz kabul edilmektedir.

Şekil 1'de görüldüğü gibi genel iş stresi gizil değişken için faktör yükleri $0.67-0.94$ arasında değişmektedir. Utrecht işe bağlılık gizil değişkenin faktör yükleri $0.83-0.91$ arasında değişmekte ve iş sağlığı ve güvenliği uygulamaları performans değerlendirme gizil değişkenin faktör yükleri ise $0.82-0.94$ arasında değişmektedir. İş sağlığı ve güvenliği uygulamaları performans değerlendirme gizil değişkeni için açıklanan varyansın \%57’i Utrecht işe bağlılık gizil değişkenin doğrudan etkisi ve eşanlı olarak hesaplanmış ve aynı 
zamanda genel iş stresi değişkenin dolaylı etkisi Utrecht işe bağlılık değişkeni tarafından aracılık edilerek elde edilmiştir.

Standardize edilmiş regresyon katsayılarına(beta) bakıldığında, genel iş stres düzeyinin işe bağlılık üzerinde negatif bir etkisi olduğu $(\beta=-0.49 ; p<0.05)$, işe bağlılık düzeyinin iş sağlığı ve güvenliği uygulamaları performans değerlendirme üzerinde ise pozitif bir etkisi $(\beta=0.76$; $\mathrm{p}<0.05)$ olduğu saptanmıştır.

Şekil 1. Modelin YEM Analizinde Gösterimi

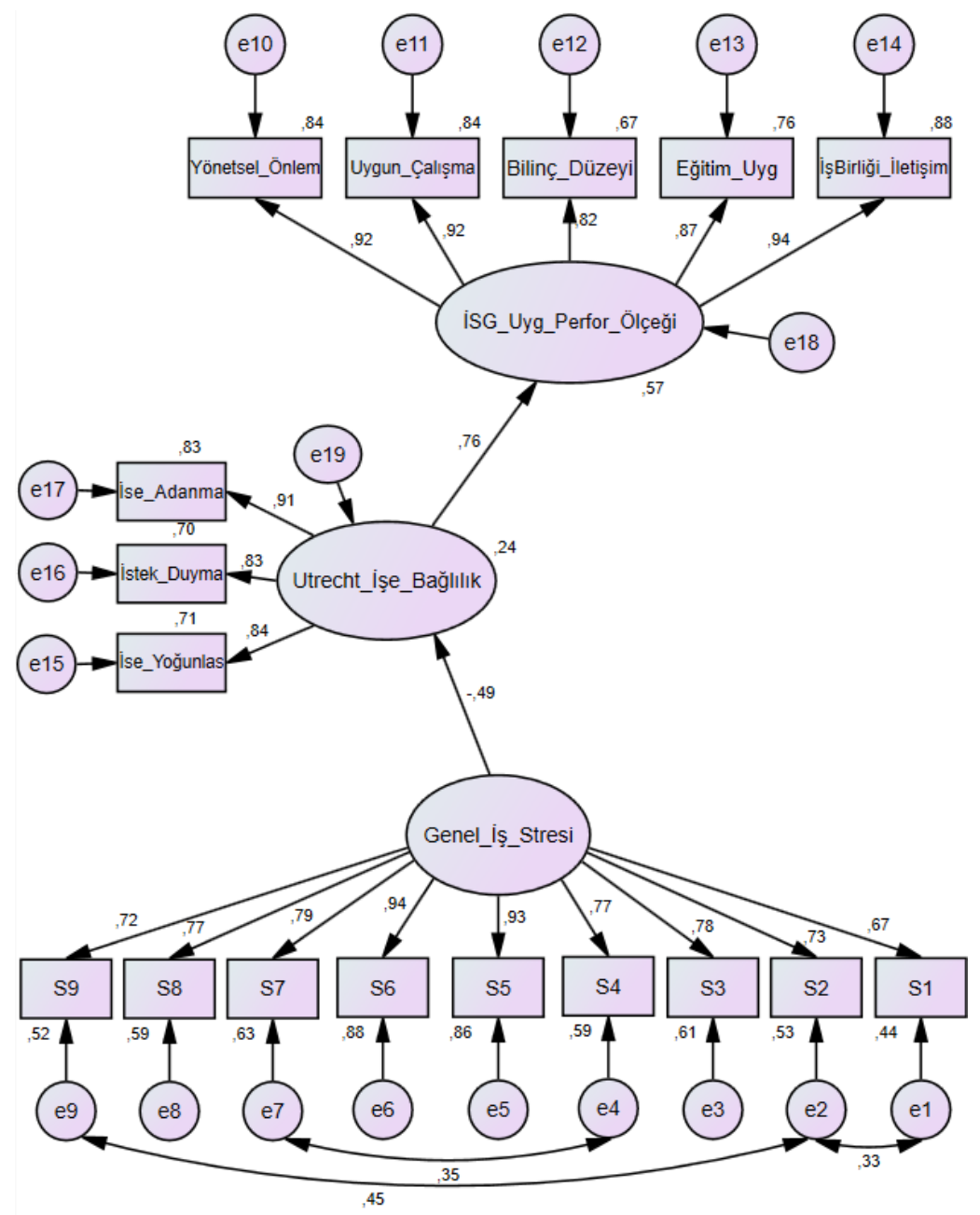

(Not: İşe Yoğunlaş: İşe Yoğunlaşma, İstek Duyma: Işse İstek Duyma, Işse Adanma: İşe Adanma, ISG Uyg Perfor Ölçeği: iSG Uygulamaları Performansı Ölçeği, Yönetsel Önlem: ISG konusunda yönetsel önlem ve tedbirler, Eğitim Uyg: ISG eğitim uygulamaları, Bilinç Düzeyi: Çalışanların ISG konusunda farkındalık ve bilinç düzeyleri, İ̧ Birliği

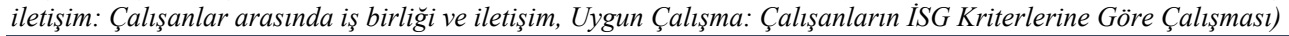

Standardize edilmiş regresyon katsayılarının 0,10 civarı küçük, 0,30 civarı orta büyüklükte ve 0,50'nin üzerindeki katsayılar ise büyük etkiler olarak yorumlanabilir. Ancak keskin sınırlar yoktur. Örneğin 0.49 ile 0.50 arasında keskin sınırlar yoktur (Korkmaz, Sünnetçioğlu ve Koyuncu, 2015). Bu bilgiye göre tasarlanan modelin standardize edilmiş regresyon 
katsayılarına baktığımızda modelin, oldukça büyük etkilerle açıklanan bir model olduğunu görüyoruz.

Tablo 5. Standardize Edilmiş Dolaylı Etkiler

\begin{tabular}{lccc}
\hline Model & Genel İş Stresi & Utrecht İşe Bağlılık & İSG Uyg Perfor Ölçeği \\
\hline Utrecht İşe Bağlılık &, 000 &, 000 &, 000 \\
\hline İSG Uyg Perfor Ölçeği &,- 374 &, 000 &, 000 \\
\hline İșe Adanma &,- 451 &, 000 &, 000 \\
\hline İstek Duyma &,- 412 &, 000 &, 000 \\
\hline İșe Yoğunlaş &,- 415 &, 000 &, 000 \\
\hline İş Birliği İletişim &,- 350 &, 709 &, 000 \\
\hline Eğitim Uyg &,- 325 &, 658 &, 000 \\
\hline Bilinç Düzeyi &,- 305 &, 617 &, 000 \\
\hline Uygun Çalışma &,- 342 &, 693 &, 000 \\
\hline Yönetsel Önlem &,- 343 &, 695 &, 000 \\
\hline
\end{tabular}

(Not: İşe Yoğunlaş: Işe Yoğunlaşma, Istek Duyma: Işse İstek Duyma, Işse Adanma: Işse Adanma, İSG Uyg Perfor Ölçeği: ISG Uygulamaları Performansı Ölçeği, Yönetsel Önlem: İSG konusunda yönetsel önlem ve tedbirler, Ĕ̌itim Uyg: ISG eğitim uygulamaları, Bilinç Düzeyi: Çalışanların ISG konusunda farkındalık ve bilinç düzeyleri, $\dot{I}_{S ̧}$ Birliği Iletişim: Çalışanlar arasında iş birliği ve iletişim, Uygun Çalışma: Çalışanların ISG Kriterlerine Göre Çalışması)

Tablo 5'te standartlaştırılmış dolaylı etkiler verilmiştir. Bu tabloya göre genel; İSG uygulamaları performans değerlendirme ve bu ölçeğin alt boyutları üzerinde olumsuz yönde etkisi olduğu görülmektedir. Yine genel iş stres düzeyinin işe bağlılığın alt boyutları üzerinde negatif bir etkisi olduğu saptanmıştır. İşe bağlılığın ise İSG uygulamaları performans değerlendirmenin alt boyutları üzerinde olumlu ve ciddi bir oranda dolaylı etkisi olduğu saptanmıştır.

\section{C- Yol Analizi}

Tablo 6. Uygulanan Modelin Uyum Kriterleri

\begin{tabular}{lcccccc}
\hline Model & P & CMIN/DF & SRMR & GFI & BIC & CFI \\
\hline Default model & $*$ & 2.57 & .05 & .90 & 164.68 & .96 \\
\hline Saturated model & & & & & 207.68 \\
\hline Independence model & & & & & \multicolumn{2}{c}{887.15} \\
\hline
\end{tabular}

** $\mathrm{p}$ değerinin 0.01 'den küçük olduğunu ifade eder, CMIN=Ki-kareyi ifade eder.

Tablo 6’ya göre uygulanan modelin uyum indekslerinin hepsi modelin iyi uyum içerisinde olduğunu göstermektedir.

Şekil 2'de görüldüğü gibi stres ile işe istek duyma, işe adanma ve İSG konusunda yönetsel önlem ve tedbirler arasındaki standardize edilmiş regresyon katsayısı sırası ile $-0.22,-0.44$ ve -0.24 olduğu saptanmıştır. İşe bağlılık ölçeğinin alt boyutu olan işe adanma düzeyi işe istek duyma, işe yoğunlaşma arasındaki standardize edilmiş regresyon katsayısı sırasıyla $0.66,0.77$ olduğu görülmektedir. Yine işe bağlılık ölçeğinin alt boyutlarından işe adanma düzeyi İSG Uygulamaları performans değerlendirme ölçeğinin alt boyutlarından; İSG konusunda yönetsel önlem ve tedbirler, İSG eğitim uygulamaları ve çalışanların İSG konusunda farkındalık ve bilinç düzeyleri arasındaki standardize edilmiş regresyon 
katsayıları sırasıyla $0.47,0.30$ ve 0.35 olarak tespit edilmiştir. İșe istek duyma ve İSG konusunda yönetim ve çalışanlar arasında iş birliği ve iletişim arasındaki standardize edilmiş regresyon katsayısı 0.13 olduğu tespit edilmiştir. İşe yoğunlaşma düzeyi ile İSG konusunda yönetim ve çalışanlar arasında iş birliği ve iletişim düzeyi arasındaki standardize edilmiş regresyon katsayısı ise 0.17 olduğu görülmektedir. ISG uygulamaları performans değerlendirme ölçeğinin alt boyutlarından olan İSG konusunda yönetsel önlem ve tedbirler düzeyi; İSG konusunda yönetim ve çalışanlar arasında iş birliği ve iletişim, İSG eğitim uygulamaları, çalışanların ISG konusunda farkındalık ve bilinç düzeyleri ve çalışanların ISG kriterlerine göre çalışması arasındaki standardize edilmiş regresyon katsayıları sırasıyla 0.73 , 0.65, 0.55, ve 0.60 olduğu saptanmıştır. Çalışanların ISG konusunda farkındalık ve bilinç düzeyleri ile çalışanların ISG kriterlerine göre çalışması arasındaki standardize edilmiş regresyon katsayısı 0.33 olduğu dile getirilmiştir.

Şekil 2. Uygulanan Modelin Yol Analiz Sonucu

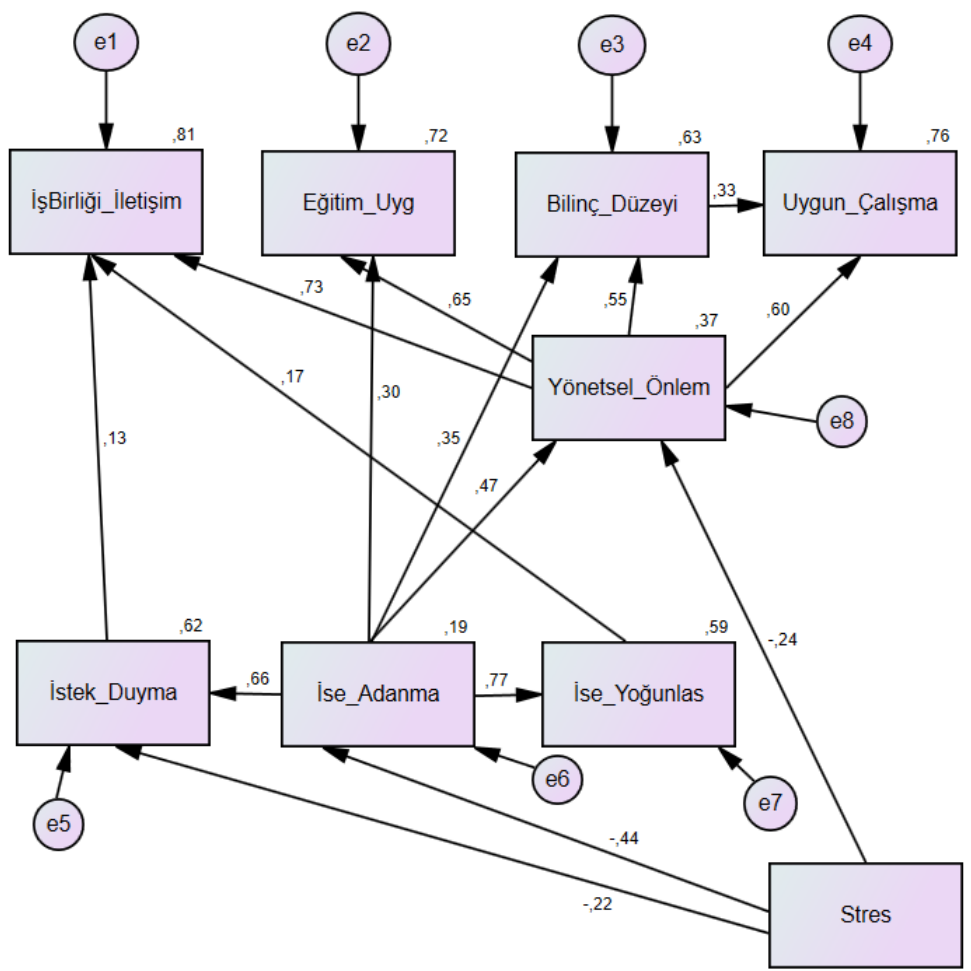

(Not: Işse Yoğunlaş: İşe Yoğunlaşma, İstek Duyma: Işse Isstek Duyma, Işse Adanma: İşe Adanma, Yönetsel Önlem: ISSG konusunda yönetsel önlem ve tedbirler, Eğitim Uyg: ISG ĕgitim uygulamaları, Bilinç Düzeyi: Çalışanların ISSG konusunda farkındalık ve bilinç düzeyleri, İş Birliği İletişim: Çalışanlar arasında iş birliği ve iletişim, Uygun Çalışma: Çalışanların ISSG Kriterlerine Göre Çalışması)

Standartlaştırılmış yol katsayıları için 0,10 civarı küçük, 0,30 civarı orta büyüklükte ve 0,50’nin üzerindeki katsayılar ise büyük etkiler olarak yorumlanabilir (Korkmaz, Sünnetçioğlu ve Koyuncu, 2015). Bu bilgiye göre tasarlanan modelin standartlaştırılmış yol katsayılarına baktığımızda modelin, oldukça büyük etkilerle açıklanan bir model olduğunu görüyoruz. Özellikle İSG konusunda yönetsel önlem ve tedbirler düzeyi aynı ölçekteki diğer alt boyutları ciddi oranda etkilemektedir. 
Şekil 2'e bakıldığında İSG konusunda yönetsel önlem ve tedbirler, İSG eğitim uygulamaları, çalışanların İSG konusunda farkındalık ve bilinç düzeyleri, çalışanların ISG kriterlerine göre çalışması ve ISG konusunda yönetim ve çalışanlar arasında iş birliği ve iletişim değişkenlerinin toplam değişimlerinin sırasıyla $\% 37, \% 72, \% 63, \% 76$ ve $\% 81$ 'i uygulanan model ile açıklanmaktadır.

\section{IV- TARTIŞMA}

Yaptığımız bu çalışmada, iş stresinin işe bağlılık üzerinde negatif etkisinin olması sonucunda, kişinin stres algısının artması ile işe bağlılık düzeyinin azaldığı görülmektedir. Bununla birlikte azalan aidiyet duygusunun iş sağlığı ve güvenliği kurallarına ve uygulamalarına bağlılık gösterme düzeyini de düşürdüğü gözlemlenmektedir. Bu çalışmayla ilgili olarak iş güvenliği profesyonelleri ile ilgili literatür azlığından dolayı diğer meslekler ile kıyaslanmak zorunda kalınmıştır.

Yapılan diğer araştırmalara göre; İş tatmini ve iş stresinin, performansın önemli birer belirleyicisi olduğu; performansın ise işten ayrılma niyetinin önemli bir belirleyicisi olduğu bulunmuştur (Tekingündüz, Top ve Seçkin: 9). Erkuş ve Fındıklı'nın (2013) çalışmasında iş tatmini ile iş performansı arasında pozitif, iş tatmini ile işten ayrılma niyeti arasında ise negatif ilişkisi gözlenmiştir. Ayrıca çalışmada performans ile işten ayrılma niyeti arasında negatif anlamlı ilişki gözlenmiştir. İş stresinin iş tatmini üzerine olan etkisini araştıran Kara'nın (2010) çalışmasında, yaptığımız çalışmanın sonucuna benzer bir şekilde, iş stresinin iş tatmini üzerine negatif yönde bir etki olduğu görülmüştür. Sağlık sektöründeki çalışanlar üzerinde yapılmış bir çalışmada ise iş tatmini ile performans arasında pozitif bir etki bulunmuşken, iş stresi ile negatif yönlü bir ilişki olduğu görülmüştür (Gül, Oktay ve Gökçe, 2008: 6). Aynı zamanda yapılan pek çok çalışma iş stresi ile çalışanların işe bağlılıkları arasında negatif yönlü doğrusal bir ilişki olduğunu ortaya koymaktadır (Zincirkıran vd., 2015: 67; Ko ve Yom, 2003: 270; Turhan vd., 2018: 1492).

Stresin, çalışanın kendisini işe adamasını, işe yoğunlaşmasını ve çalışma isteğini olumsuz yönde etkilediği Şekil 2'te verilen yol analizi şemasında görülmektedir. Yapılan bir çalışmada, örgütsel stresin örgütsel bağlılığı azalttığı görülmüştür (Bilgili ve Tekin, 2019: 2183). Bir sağlık kurumunda yapılan çalışmada ise, iş stresi ile örgütsel sağlık arasında olumsuz; örgütsel sağlık ile çalışan performansı arasında olumlu yönde anlamlı ilişkilerin olduğu görülmüştür. Örgütlerin sağlıklı bir yapıya kavuşmak için öncelikle iş stresinin ortadan kaldırılması veya en az seviyeye indirilmesi gerektiği sonucuna varılmıştır (Gül, 2007: 329).

Yüksek riskli sektörde yapılan bir araştırmaya göre İSG uzmanlarının çalışanların güvenliğini yönetmede kilit aktörler olduğu ifade edilmiştir (Guennoc, Chauvin ve Le Coze, 2019: 71). Bu çalışma da gösteriyor ki stres ve işe bağlılığın İSG Uygulamalarını ve performansını etkilemektedir. Bu nedenle İSG uzmanları üzerindeki stresin azaltılması gerekmektedir.

İş sağlığı ve güvenliği açısından bakıldığında yönetim ve çalışanlar arasındaki iş birliği ve iletişimin, farkındalık, eğitim ve İSG Uygulamalarına bağlılıkları arasında güçlü bir ilişki olduğu Şekil 2'de görülmektedir. İletişim ve yönetimin güvenlik kültürüne olan etkisini araştıran bir çalışmada, güçlü ve olumlu sağlık ve güvenlik kültürün oluşturulmasında tüm çalışanların her seviyede dahil edilmesi gerektiği ve kurum içi iletişim fırsatlarının işletme kültürünün sağlık ve güvenliği destekleyen olumlu bir hale dönüştürülmesi gerektiği belirtilmiştir (Sungur ve Şerfioğlu, 2007: 49). 


\section{SONUÇ}

Gerek geçmiş çalışmalar gerekse de yapılan bu çalışmalar, iş stresinin hem çalışanın kendini adaması, çalışma isteği gibi dolaylı yollarla hem de doğrudan işyerine olan aidiyet duygusunu olumsuz yönde etkilediğini göstermektedir. Bununla birlikte iş stresinin yoğun olduğu kişilerin gerek örgütsel olarak gerekse de iş sağlığı ve güvenliği uygulamalarına olan bağlılığını da olumsuz yönde etkilediği görülmektedir.

Yapılan bu çalışmanın sonucunda, iş kazalarının azaltılması ve güvenlik kültürünün sağlanması için yönetimin ve kurum içi iletişimin mutlak derecede üst düzeylerde olması, bununla birlikte çalışanın, işyerine olan aidiyet duygusunu ve performansını arttırmak için iş stresinin ortadan kaldırılması veya kişiyi etkilemeyecek şekilde en az düzeylere indirgenmesinin gerektiği sonucuna varılabilir.

Yapılan yol analizinde görülmektedir ki stres, işe bağlılık özellikle İSG Uygulamaları performans değerlendirme ölçeğinin alt boyutu olan ISG konusunda yönetsel önlem ve tedbirleri etkilemekte ve bu alt boyut aynı ölçeğin diğer bütün alt boyutlarını etkilemektedir. Bu da göstermektedir ki stres örgüt için bireysel bir sorun değil aynı zamanda örgütsel bir sorun olarak İSG Uygulamalarının yönetimsel tedbirlerinden diğer alt boyutların etkinliğini azaltmakta bu da İSG için sorun teşkil etmektedir.

Cohen vd. (2006), iş kazaları ve meslek hastalıklarının mali yükünün, kanser, Alzheimer vb. hastalıklarla karşılaştırıldığında daha yüksek olduğunu ortaya koymuştur. İş stresinin ve işe bağlılı̆̆ın İSG performansı üzerine etkisi göz önünde bulundurulduğunda gerek kamu kurum ve kuruluşların gerekse de özel sektördeki kurumların çalışanlara stressiz bir çalışma ortamı sağlayarak çalışanların performanslarını ve işe bağlılıklarını arttırması gerekmektedir

\section{Kaynakça}

Abidi, J. ve Sharma, D. (2014). Poverty, Disability and Employment: Global Perspectives From the National Centre for Promotion of Employment for Disabled People. Career Development and Transition for Exceptional Individuals. 37(1). 60-68.

Akgemci, T. (2001). Örgütlerde Stres ve Yönetimi. Atatürk Üniversitesi İktisadi ve İdari Bilimler Dergisi. 15(1-2). 302-309.

Alipour, F. ve Monfared, M. K. (2015). Examining the Relationship Between Job Stress and Organizational Commitment Among Nurses of Hospitals. Journal of Patient Safety \& Quality Improvement. 3(4). 277-80. doi: 10.22038/psj.2015

Amerika Stres Kurumu (2021). The American Institute of Stress. [https://www.stress.org/ workplace-stress]. (Erişim: 7 Nisan 2021).

Atilla, E. (2017). Tarım Arazilerinde Ulaşım Kaynakl Toprak Kirliliği Denizli Örneği. (Yüksek Lisans Tezi). Pamukkale Üniversitesi Fen Bilimleri Enstitüsü. Pamukkale.
Aytaç, M. ve Öngen, B. (2012). Doğrulayıcı Faktör Analizi ile Yeni Çevresel Paradigma Ölçeğinin Yap1 Geçerliliğinin İncelenmesi. İstatistikçiler Dergisi: İstatistik ve Aktüerya. 5(1). 14-22.

Bass, B. M. (1965). Organizational Psychology. Boston: Allyn and Bacon.

Bayram, N. (2010). Yapısal Eșitlik Modellemesine Giriş AMOS Uygulamaları. Bursa: Ezgi Kitabevi.

Bhagawati, B. (2015). Basics of Occupational Safety and Health. Journal of Environmental Science. Toxicology and Food Technology. 9(8). 91-94. doi: 10.9790/2402-09819194

Bilgili, H. ve Tekin, E. (2019). Örgütsel Stres, Örgütsel Bağlllık ve Öğrenilmiş Güçlülük İlişkisi Üzerine Bir Araştırma. OPUS Uluslararast Toplum Araştırmalart Dergisi. 11(18). 2165-2200. doi: 10.26466/opus.557530 
Brown, S. P. (1996). A Meta-Analysis and Review of Organizational Research on Job İnvolvement. Psychological Bulletin. 120(2). 235. doi: 10.1037 / 0033-2909.120.2.235

Bryne, B. M. (2001), Structural Equation Modeling With AMOS Mahwah, NJ: Lawrence Erlbaum Associates.

Cho, J. J., Kim, J. Y., Chang, S. J., Fiedler, N., Koh, S. B., Crabtree, B. F., Kang, D. M., Kim, Y. K. And Choi, Y. H. (2008). Occupational Stress and Depression in Korean Employees. Int Arch Occupational Environment Health. 82. 47.57. doi: 10.1007/s00420-008-0306-4

Cohen, M. A., Clark, R. E., Silverstein, B., Sjostrom, T. ve Spielholz, P. (2006). WorkRelated Deaths in Washington State. 1998-2002. Journal of Safety Research. 37(3). 307-319.

Comrey, A. L. ve Lee, H. B. (2013). A First Course In Factor Analysis. NewYork: Psychology Press.

Cooper, C. L., Sloan, S. J. ve Williams, S. (1988). Occupational Stress Indicator: Management Guide. Firenze: Windsor: NFERNelson.

Çınar, O. ve Gündoğdu, M. (2019). İş Sağlığ1Güvenliği, İş Tatmini ve Örgütsel Bağlılık Arasındaki İlişkinin İncelenmesi: Erzurum ve İstanbul Uygulaması. İş ve Hayat. 5(9). 231-247.

Danish, R. Q., Ramzan, S. ve Ahmad, F. (2013). Effect of Perceived Organizational Support and Work Environment on Organizational Commitment; Mediating Role of SelfMonitoring. Advances in Economics and Business. 1(4). 312-317. doi: 10.13189/aeb.2013.010402

Dubinsky, A. J. ve Hartley, S. W. (1986). A Path-Analytic Study of a Model of Salesperson Performance. Journal of the Academy of Marketing Science.14(1). 36-46. doi: 10.1007/BF02722111

Efeoğlu, D. ve Özgen, P. (2007). İş-Aile Yaşam Çatışmasının İş Stresi, İş Doyumu ve Örgütsel Bağlılık Üzerindeki Etkileri: İlaç Sektöründe Bir Araştırma. Çukurova Üniversitesi Sosyal Bilimler Enstitüsü Dergisi. 16(2). 237-254.

Elloy, D. F., Everett, J. E. ve Flynn, W. R. (1995). Multidimensional Mapping of the Correlates of Job Involvement. Canadian Journal of Behavioural Science / Revue Canadienne Des Sciences Du Comportement 27(1). 79-91. doi: 10.1037/008-400X.27.1.79
Erkuş, A. ve Fındıklı, M. A. (2013). Psikolojik Sermayenin İş Tatmini. İş Performansı ve İşten Ayrılma Niyeti Üzerindeki Etkisine Yönelik Bir Araştırma. İstanbul Üniversitesi İşletme Fakültesi Dergisi. 42(2). 302-318.

Eryılmaz, A. ve Doğan, T. (2012). İş Yaşamında Öznel İyi Oluş: Utrecht İşe Bağlllık Ölçeğinin Psikometrik Özelliklerinin İncelenmesi. Klinik Psikiyatri Dergisi. 15(1). 49-55.

Gorsuch, R. L. (1983). Factor Analysis. Hillsdale. NJ: Erlbaum.

Guennoc, F., Chauvin, C. ve Le Coze, J. C. (2019). The Activities of Occupational Health and Safety Specialists In A High-Risk Industry. Safety Science. 112. 71-80. doi: 10.1016/j.ssci.2018.10.004

Güçlü, N. (2001). Stres Yönetimi. Gazi Eğitim Fakültesi Dergisi. 21(1). 91-109.

Gül, H., Oktay, E. ve Gökçe, H. (2008). İş Tatmini, Stres, Örgütsel Bağlllık, İşten Ayrılma Niyeti ve Performans Arasındaki İlişkiler: Sağlik Sektöründe Bir Uygulama. Akademik Bakış, Uluslararası Hakemli Sosyal Bilimler eDergisi. 20. 1-11.

Gül, H. (2007). İş Stresi, Örgütsel Sağlık ve Performans Arasındaki İlişkiler: Bir Alan Araştırması. KMU Iktisadi ve İdari Bilimler Dergisi. 318-332.

Hakanen, J. J., Bakker, A. B. ve Schaufeli, W. B. (2006). Burnout and Work Engagement Among Teachers. Journal of School Psychology. 43(6). 495-513. doi: 10.1016/j.jsp.2005.11.001

Hsu, I. Y., Su, T. S., Kao, C. S., Shu, Y. L., Lin, P.R. ve Tseng, J. M. (2012). Analysis of Business Safety Performance By Structural Equation Models. Safety Science. 50(1). 1-11. doi: 10.1016/j.ssci.2011.04.012

İş Sağllğ 1 ve Güvenliği Kanunu. No: 6331. (2012). Resmi Gazete. S. 28339. 30 Haziran 2012.

Kara, T. (2010). Hemşirelerde Stresin Ișs Tatmini ve İşten Ayrllmaya Etkisinin Çalışma Saatleri Açısından Değerlendirilmesi. (Yayınlanmamış Yüksek Lisans Tezi). Beykent Üniversitesi Sosyal Bilimler Enstitüsü. İstanbul.

Kılıç, K. C., Efeoğlu, İ. E., Mimaroğlu, H. ve Özgen, H. (2008). Adana İlindeki Özel Sağlık Merkezlerinde Çalışan Personelin İş-Aile Yaşam Çatışmasının Örgütsel Bağlılık. İş Doyumu ve İş Stresine Etkisi Üzerine Bir Araştırma. Çukurova Üniversitesi Sosyal Bilimler Enstitüsü Dergisi. 17(2). 241-254. 
Yapısal Eşitlik Modelleme Çalışması

Kinman, G. ve Jones, F. (2003). Running Up the Down Escalator: Stressors and Strains in UK Academics. Quality in Higher Educatio. 9(1). 21-38. doi: $10.1080 / 13538320308162$

Kline, P. (1979). Psychometrics and Psychology. London: Acaderric Press.

Kline, R. B. (2010). Principles and Practice of Structural Equation Modeling.3rd Edition. New York: Guilford Press.

Ko, J. W. ve Yom, Y. H. (2003). The Role of Social Support in the Relationship Between Job Stress and Job Satisfaction/Organizational Commitment Among Hospital. Nurses. Journal of Korean Academy of Nursing. 33(2). 265- 274. doi: 10.4040 / jkan.2003.33.2.265

Lawler, E. (1992). The Ultimate Advantage: Creating The High-Involvement Organization. San Francisco: Jossey-Bass.

Leka, S. (2003). Occupational Health and Safety Practices in Small and Medium-Sized Enterprises: A Comparative Study Between England and Greece. (Doctoral dissertation). University of Nottingham. England.

Leung, M. Y., Yu, J. ve Chong, M. L. A. (2015). Effects of Stress and Commitment on the Performance of Construction Estimation Participants in Hong Kong. Journal of Construction Engineering and Management. 142(2). doi:10.1061/(ASCE)CO.19437862.0001059

Lin, L. C., Huang, P. H. ve Weng, L. J. (2017). Selecting path models in SEM: A Comparison of Model Selection Criteria. Structural Equation Modeling: A Multidisciplinary Journal. 24(6). 855-869. doi: 10.1080/10705511.2017.1363652

Lodahl, T. M. ve Kejner, M. M. (1965) The Definition and Measurement of Job Involvement. Journal of Applied Psychology. 49. 24-33. doi: 10.1037/h0021692

Mac Callum, R. C. ve Hong, S. (1997). Power Analysis In Covariance Structure Modeling Using GFI and AGFI. Multivariate Behavioral Research. 32(2). 193-210.

Michael, J. H., Evans, D. D., Jansen, K. J. ve Haight, J. M. (2005). "Management Commitment to Safety as Organizational Support: Relationships With Non-Safety Outcomes In Wood Manufacturing Employees”. Journal of Safety Research. 36.171- 179. doi: 10.1016/j.jsr.2005.03.002
Mokarami, H., Alizadeh, S. S., Pordanjani, T. R. ve Varmazyar, S. (2019). The Relationship Between Organizational Safety Culture and Unsafe Behaviors and Accidents Among Public Transport Bus Drivers Using Structural Equation Modeling. Transportation research part F: traffic psychology and behaviour. 65. 46-55. doi: 10.1016/j.trf.2019.07.008

Newbury-Birch, D. ve Kamali, F. (2001). Psychological Stress, Anxiety, Depression, Job Satisfaction, and Personality Characteristics In Preregistration House Officers. Postgraduate medical journal. 77(904). 109-111.

Rotenberry, P. F. ve Moberg, P. J. (2007). Assessing the Impact ff Job İnvolvement on Performance. Management Research News. 30.203-215. Psychology63. 53.61. doi: 10.1136/pmj.77.904.109

Schaufeli, W. B., Salanova, M., GonzálezRomá, V. ve Bakker, A. B. (2002). The Measurement of Engagement and Burnout: A Two Sample Confirmatory Factor Analytic Approach. Journal of Happiness Studies. 3(1). 71-92. doi: 10.1023/A:1015630930326

Schuler, R. S. (1980). Definition and Conceptualization of Stress in Organizations. Organizational Behavior and Human Performance. 25. 184-215. doi: 10.1016/00305073(80)90063-X

Selye, H. (1976). Stress without Distress. In Psychopathology of Human Adaptation (pp. 137-146). Boston: Springer, doi: 10.1007/9781-4684-2238-2_9

Sevim, L. (2011). Tükenmişlik ve İşe Bağlılığın Örgütsel Vatandaşlık Davranışı Üzerindeki Etkisi: Turizm Sektöründe Bir Araştırma. Ankara: Hacettepe Üniversitesi.

Sungur, E. ve Şerfioğlu, U. K. (2007). İşletmelerde Sağlık ve Güvenlik Kültürünün Oluşturulması; Tepe Yönetimin Rolü ve Kurum İçi İletişim Olanaklarının Kullanımı. Yönetim Dergisi. 18(58). 41-50.

Şahin, B. (2014). Seyahat Acentas1 Çalışanlarında Örgütsel Stresin Örgütsel Bağll1ıkla İlişkisi Üzerine Bir Araștırma: İstanbul Örneği. Balıkesir Üniversitesi Sosyal Bilimler Enstitüsü Dergisi. 17 (32). 193-210.

Tekingündüz, S., Top, M. ve Seçkin, M. (2015). Verimlilik İş Tatmini, Performans. İş Stresi ve İșten Ayrılma Niyeti Arasındaki İlişkilerin İncelenmesi. Hastane Örneği Dergisi. (4). 3964. 
Teleş, M. (2020). Validity and Reliability of the Turkish Version of the General Work Stress Scale. Journal of Nursing Management. 1.11. doi: 10.1111/jonm.13211

Turhan, M., Erol, Y. C., Demirkol, M. ve Özdemir, T. Y. (2018). Örgütsel Bağllık, İşs Doyumu ve İş Stresi Arasındaki İliş̧ki. Turkish Studies Educational Sciences. 13(27). 14911507. doi: 10.7827/TurkishStudies.14328

Uzun, Ö. ve Yiğit, E. (2011). Örgütsel Stres ve Örgütsel Bağlllık İlişsisi Üzerine Orta Kademe Otel Yöneticileri Üzerinde Yapılan Bir Araştırma. Eskişehir Osmangazi Üniversitesi İktisadi ve İdari Bilimler Dergisi. 6(1). 181-213.

Üngüren, E. ve Koç, T. S. (2015). İş Sağlığı ve Güvenliği Uygulamaları Performans Değerlendirme Ölçeği: Geçerlik ve Güvenirlik Çalışması. (SGD) Sosyal Güvenlik Dergisi. 5(2). 124-144.

WHO (1995). [https://www.who.int/whr/1995/ en/whr95_en.pdf?ua=1]. (Erişim: 07 Nisan 2021)

Zincirkıran, M., Çelik, G. M., Ceylan, A. K. ve Emhan, A. (2015). İşgörenlerin Örgütsel Bağlılık, İşten Ayrılma Niyeti, İş Stresi ve İş Tatmininin Örgütsel Performans Üzerindeki Etkisi: Enerji Sektöründe Bir Araştırma. Finans Politik \& Ekonomik Yorumlar Dergisi. 52(600).59-71. 